\title{
The authoritarian logic of regulatory pluralism: Understanding China's new environmental actors
}

\author{
Benjamin van Rooij \\ School of Law, University of California, Irvine, CA, USA \\ Rachel E. Stern \\ School of Law, University of California Berkeley, Berkeley, CA, USA \\ Kathinka Fürst \\ Faculty of Law, University of Amsterdam, Amsterdam, The Netherlands
}

\begin{abstract}
Over the last decade, Chinese citizens, judges, and prosecutors have started to take action against industrial pollution, pluralizing a regulatory landscape originally occupied by administrative agencies. Regulatory pluralism here has an authoritarian logic, occurring without the retreat of party-state control. Under such logic, the party-state both needs and fears new actors for their positive and negative roles in controlling risk and maintaining stability. Consequently, the regime's relation to regulatory pluralism is ambivalent, shifting between support and restriction. This prevents a development of a regulatory society that could bypass the regulatory state. Theoretically, this special edition argues for a subjective definition of regulation in a context of pluralism. Moreover, it finds that regulatory pluralism need not coincide with a decentring of regulation. Finally, it highlights how entry onto the regulatory landscape affects the non-regulatory roles of new actors, creating unintended consequences for regulatory pluralism.
\end{abstract}

Keywords: authoritarianism, China, Global South, environmental regulation, regulatory pluralism.

\section{Introduction: Painting the regulatory landscape}

The regulatory landscape is comprised of multiple actors who engage in activities that, intentionally or not, help prevent and control human-made risk. ${ }^{1}$ To start, this landscape ${ }^{2}$ is inhabited by the bureaucrats and legislators traditionally associated with the regulatory tasks of gathering information, setting standards, and changing behavior (Hood et al. 2001, p. 22). At the same time, the landscape also contains actors whose core roles, goals, and identities were not originally regulatory, and who have undergone a transformation. One can think, for instance, of citizens or citizen groups, banks, courts, industry associations, and civic organizations that now play a regulatory role (Gunningham et al. 1998).

This special issue studies the pluralization of China's regulatory landscape by analyzing the entry and impact of new actors whose regulatory roles parallel the work of traditional administrative agencies. In so doing, it adds a unique case to the literature on regulatory pluralism,

Correspondence: Benjamin van Rooij, School of Law, University of California, Irvine, CA 92617, USA. Email: bvanrooij@law.uci.edu

Accepted for publication 29 August 2014. 
which has predominantly focused on high-income liberal democracies (i.e. Gunningham et al. 1998; Black 2001). It also adds an important case to an emerging literature on the regulatory state in the South (i.e. Braithwaite 2006; Chng 2012; Dubash \& Morgan 2012) that has not commonly focused on the role of regulation in authoritarian settings. ${ }^{3}$ For students of regulation, the Chinese case raises a new set of interesting questions. Why and how would a regulatory space to new actors open up in an authoritarian system? How does the nature of authoritarianism influence new actors' ability to reduce risk? And what does the existence of regulatory pluralism in an authoritarian setting mean for existing ideas about decentered regulation?

Our focus here is one aspect of China's regulatory landscape: environmental protection. Over the past decade, environmental regulation in China has become increasingly pluralized, with active involvement by citizens, civic organizations, financial institutions, trade associations, courts, and prosecutors. China, of course, is quite different from both liberal democracies and other developmental states. Overall, it is a country that has pursued a bifurcated regulatory strategy of macro-liberalization in some sectors and strong state regulation in others (Hsueh 2011). Most important for our analysis here, it is a one party state, with a resilient form of authoritarian rule (cf. Nathan 2003). Recently, China has shown a remarkable shift toward what some call "responsive authoritarianism" (cf. Cai 2004; Weller 2008; He \& Warren 2011; Weller 2012; Reilly 2011). New channels for public feedback and party-state coordination include direct local elections, public hearings, access to courts, social media, and even protest (cf. Minzner 2006; Lorentzen 2013; Stockmann 2012; Van Rooij 2012). Under responsive authoritarianism, all levels of the Chinese government walk a fine line between tolerating (and sometimes even encouraging) public participation and expression on the one hand, and controlling society on the other (cf. Stockmann 2012).

The articles in this special edition are case studies of new actors emerging on the regulatory landscape, and grew out of an August 2012 symposium on the implementation of environmental law. The first paper, by Thomas Johnson, chronicles how protests over a waste incinerator project in Guangzhou snowballed into broader demands for transparency and public consultation as part of the regulatory process. The second paper, by Xuehua Zhang, looks at the role that administrative judges can play in improving compliance with pollution discharge fee payment. Finally, Yifan Shi and Benjamin Van Rooij's paper examines how Chinese prosecutors have started to bring civil lawsuits against polluters, comparing initial efforts to the tremendous success of prosecutor-led environmental litigation in Brazil.

The special issue, thus, profiles three new actors on the environmental regulatory landscape in China: citizens, prosecutors, and judges. These actors were chosen for their importance, as well as for the depth of information available. Of course, no single edition of a journal can provide a full overview of the actors involved in Chinese environmental regulation. For example, various types of economic non-state actors, such as banks, insurance companies, and business associations are not covered in these pages. These gaps provide rich ground for future research and, in coming years, we certainly hope to see them filled by new work. For now, though, we see the following themes emerging from the studies presented here: the conditions for taking on a regulatory role, the effect of new actors on regulatory capacity and autonomy, and the unintended consequences of this transformation.

\section{Conditions for regulatory transformation}

So far, existing literature has paid scant attention to how new actors start playing a regulatory role. In many studies, it is implicitly described, hoped, predicted, or assumed that non-state or 
other new actors become involved in regulatory activities at some point (e.g. Ayres \& Braithwaite 1992; Gunningham et al. 1998; Hutter 2006). Few have reflected on the factors that propel (or restrict) such transformation and instead pointed broadly to broad, transformative forces, such as globalization, liberalization, privatization, and governmental failure (i.e. Peters et al. 2009; Grabosky 2012). ${ }^{4}$ A different vein of scholarship seeks to understand how new and non-state forms of regulation and regulatory institutions arise, stressing the importance of the local conditions and the interaction between the state, social movements, and regulated actors (cf. Bartley 2003, 2007). Chng (2012), for example, details how regulatory mobilization by nongovernment organizations (NGOs) in Manila occurs in a regulatory space fragmented by market liberalization, privatization of state sectors, and weak state regulation. As yet, however, we still lack a detailed account of why new actors start playing regulatory roles. Of course, scholars of contentious politics have long been interested in the question of why some citizens take action to protect their interests and others let complaints slide (cf. Snow et al. 1998; Blecher 2002; Holzner 2004; Michelson 2007; Van Rooij 2010). This literature may have crucial insights for those interested in the emergence of non-state regulators, especially citizens and civic organizations. However, most regulatory scholars have yet to draw on this work to understand what motivates or discourages entry onto the regulatory landscape. ${ }^{5}$ In fact, one theme of the three papers that follow is the endogenous and exogenous factors that stimulate regulatory transformation.

To start, an overarching exogenous force is China's extreme industrial pollution (cf. World Bank/State Environmental Protection Administration 2007, Organisation for Economic Co-operation \& Develoment 2007). All of the papers in this special edition suggest a major reason for the entry of new actors is increasing concern - both inside the party-state and in society - about the impact of pollution on health, the economy, and social stability. ${ }^{6}$ In response, the Chinese government has certainly sought to strengthen environmental bureaucracy. The number of Environmental Protection Bureau (EPB) staff increased from 70,000 to well over 170,000 between 1991 and 2007, during which time government spending on environmental protection jumped from RMB 10 billion (US 1.6 million) to RMB 340 billion (US 54 million) (Mol 2009, p. 96). As discussed further, central leadership has also opened space for new actors to help curb environmental risks (cf. Van Rooij 2012), through new laws and changes to the bureaucratic evaluation system.

A second critical external force is the failure of government regulators, a factor also discussed in Grabosky's (2012) overview of how regulatory pluralism develops. In the papers discussed here, this is the failure (both real and perceived) of China's main environmental agency, the EPB. As has been documented elsewhere (Ma \& Ortolano 2000; Lo \& Tang 2006; Tilt 2007; Van Rooij and Lo 2010), local EPBs struggle to implement environmental law without sufficient funding, staff, and autonomy. Over the last decade or so, the EPB's shortcomings have created the demand and space for new actors to play a role. All of the papers speak to this theme. Johnson's contribution shows that citizens protested when EPBs failed to properly conduct Environmental Impact Assessments (EIAs) for a waste incinerator in a Guangzhou neighborhood. Shi and Van Rooij connect the rise of prosecutorial litigation against polluters to weak administrative regulation. Zhang's paper argues that EPB weakness was a key reason the agency turned to the courts for help. Together, the papers illustrate how the combination of increasing environmental concern and regulatory failure set the stage for new actors to enter the regulatory landscape.

Legal changes also enabled entry. In the 2000s, new national laws and amendments sanctioning the participation of new actors in regulatory activities further eased entry 
into the regulatory landscape (Van Rooij 2012). The local judges involved in non-litigation administrative execution cases, for example, could help the EPB collect fines because Chinese administrative law vested them with the authority to do so. In addition, lack of public participation could become a focal point for activism because citizens were granted the right to a public hearing under the 2002 EIA law. As Johnson points out, new rules can be a useful entry point for activism, even when they are ignored.

Regulatory transformation is further shaped by bureaucratic evaluation standards and incentives. For actors inside the Chinese bureaucracy, the national civil service evaluation system (the kaohe system in Chinese ${ }^{7}$ ) provides vital behind-the-scenes guidance to central and local level civil servants and politicians. Shi and Van Rooij argue that extra kaohe credit for innovation was the main reason Chinese prosecutors brought environmental public interest cases. Ironically, prosecutors may be slower to sue now that the 2012 amendments to the Civil Procedure Law have legalized their right to initiate environmental public interest litigation, as it is no longer innovative to do so. Zhang's work demonstrates how bureaucratic targets matter in another way as well: local courts were eager to help environmental regulators collect fines because nonlitigation administrative execution cases (NAECs) also helped them meet national targets for administrative litigation caseloads. A broader implication, detailed in Shi and Van Rooij's contribution, is that what may appear to be innovative local experiments may actually be guided by national targets and incentives. The cadre evaluation system serves as a "shadow of hierarchy" (Sabel \& Zeitlin 2008), which aligns local experiments with national targets. It is ironic that the same national evaluation system that rewards bureaucratic innovation does not always reward risk taking.

In contrast to the existing work that suggests the state plays a supporting role as regulatory pluralism develops (cf. Bartley 2003, 2007; Grabosky 2012), the articles presented here show how entry is both enabled and restricted by different levels of Chinese officials. For judges, Zhang's paper discusses penalties for courts with a high percent of appeals, retrials, or petitions or a low level of case completion, mediation, and execution rates (Fu \& Cullen 2007; Su \& He 2010; Liebman 2011; Minzner 2011). Courts lack incentives to accept environmental cases, especially politically sensitive disputes in which polluters are large employers with political clout. Environmental cases are also not easily mediated or executed, as complainants are often angry and radicalized by the time the case reaches court. For prosecutors, as Shi and Van Rooij highlight, the most important incentives revolve around crime reduction targets that do not mention environmental crime, let alone environmental public interest litigation. Here an authoritarian logic is at play: the fear is that new environmental actors may cause unrest and stir up dissatisfaction with those in power. At the same time, both Johnson's piece and earlier work show that citizen environmental activism is held back by a state that tightly controls information, often fails to respond to complaints, and places restrictions on freedom to organize (Lora-Wainwright 2012; Van Rooij et al. 2012).

Entry of new actors onto the regulatory landscape is equally shaped by their own endogenous characteristics. This is clearest with Chinese citizens. Contrasting Johnson's paper of successful entry by urban residents and earlier studies on rural environmental activism (Lora-Wainwright 2012; Van Rooij et al. 2012), we see several factors that shape possibilities for activism aimed at reducing risk. A first point of difference is the degree of community cohesion, with urban communities opposing new waste incinerators by up to 97 percent, and rural residents showing much more disagreement. A second difference is the degree of organization, an essential component of mobilization, which was much higher in urban cases than in rural ones. More surprising, environmental awareness does not stand out as a difference between the 
cities and the countryside. Both successful urban entrants, as well as less successful rural citizens, well understood the danger of pollution (cf. Lora-Wainwright et al. 2012).

Looking at the courts and at the prosecutors, we get a somewhat different set of variables. Here, the preconditions for entry relate to bureaucratic strength and weakness. In some of the cases studied by Shi and Van Rooij, prosecutors were asked to support public interest litigation because their relative bureaucratic strength might help the weaker EPB. To some extent, prosecutors also had the necessary knowledge and capacity to initiate civil litigation, thanks to specialized civil affairs divisions developed to oversee civil trials and aid litigants. Zhang shows that administrative judges were similarly asked to aid EPBs because of the more extensive coercive power of the courts to enforce fines.

Revenue is also important. Zhang's work on collaboration between local courts and environmental regulators shows that judicial incentives went beyond the need to meet national targets for administrative litigation caseloads. The courts were also enticed by the prospect of winning a share of the pollution discharge fees collected and, over time, court budgets came to rely on this revenue. At the same time, courts started to incentivize administrative execution cases by introducing internal bonus mechanisms to spur judges to collect more fees. Administrative execution cases, Zhang argues, were especially profitable for courts because they could keep some of the pollution fines collected, as well as the processing fees paid by EPBs.

Finally, local context and history play a major role in shaping how new actors emerge on the regulatory landscape (Bartley 2003, 2007). For China, the development of a more responsive form of authoritarianism (cf. Cai 2004; Weller 2008; He \& Warren 2011; Reilly 2011) goes a long way toward explaining what Stern terms the party-state's "political ambivalence" toward regulatory pluralism (Stern 2013). On the one hand, many central and local officials appreciate the value of new actors who can help collect information, pressure polluters, and help enforce the law. At the same time, however, there is always a danger that environmental activism could spiral into broader political complaint. This tension shapes the regulatory landscape. Although many new environmental actors have been granted implicit (and sometimes explicit) permission to enter the regulatory landscape, space for activism remains limited.

\section{Capacity and autonomy}

What does entry of new actors on the regulatory landscape mean for regulation? Or, as Grabosky (2012, p. 12) puts it in his recent overview of the literature on regulatory pluralism: "can independent private regulatory institutions fill a gap left by the state?" The contributions to this special edition provide some initial insight, while also pointing to a area for future research. As has been clear for some time, China's existing local regulators struggle to implement environmental regulations. Two issues are at the center of this implementation deficit: (i) a lack of financial, organizational, technical, human, and political capacity; and (ii) a lack of autonomy vis-a-vis regulated enterprises (cf.van Rooij and McAllister 2014). How, then, does the entry of new actors affect overall regulatory capacity and autonomy? One way to start to answer this question is by looking at two core regulatory jobs: detecting violations of the law and responding to them (cf. Van Rooij 2012).

In theory, citizens could play a vital role in identifying violations of the law because they often have direct daily information concerning on-the-ground pollution. In prior work on pollution regulation by China's rural residents, we see that often citizens are long aware of local 
pollution and law-breaking (see also Van Rooij et al. 2012). And when a local government broke its own EIA procedures, for example Johnson's urban residents were able to unearth relevant information. However, access to information is not automatically linked to a reduction in environmental risk. In a prior study of rural environmental activism in the Yunnan Province, citizens kept information about illegal behavior inside their community. Their failure to attract outside attention reflected tenuous social cohesion, limited leadership, and lack of trust in either the state or the media (cf. Van Rooij et al. 2012). The other key factor in the Yunnan case was lack of autonomy from local industry, as village leaders became co-opted by local factories and villagers profited from polluting enterprises. In Johnson's paper, in contrast, we see that urban activists deployed information about EIA transgressions to rally the local community and pressure authorities. Here, in contrast to the Yunnan case, activists had strong leadership, organization, and social capital. They also trusted the state and did not stand to profit from the planned incinerators.

Zhang's research shows how better enforcement can emerge when the relative power and capacity of the court is combined with the environmental mission of the EPB. Collaboration between courts and EPBs lent environmental regulators legal expertise, an advantage to maintaining their autonomy in enforcement work. Zhang's findings echo Thiruvengadam and Joshi's (2012) finding that courts in the Global South can play a more important role aiding weak administrative regulators than is typically possible in the Global North. At the same time, however, Zhang's study shows that EPBs continued to routinely hand out large reductions in fines even after court involvement improved polluters willingness to pay something. In other words, cozy relations between enterprises and the local government persisted even after courts entered the regulatory landscape. EPBs also primarily fined private sector firms with little pollution, such that court involvement ultimately had only a limited effect on environmental outcomes.

Through public interest litigation, prosecutors have also been able to boost the enforcement capacity of EPBs. Shi and Van Rooij find that listing prosecutors as plaintiffs or supporting plaintiffs in environmental cases improves the odds the court will hear a case. In the cases studied, the presence of prosecutors also improves the odds of winning injunctions and compensation compared to ordinary civil cases. In all of the cases studied, however, prosecutors depended on local EPB support, as they lacked the technical and legal expertise to bring environmental lawsuits themselves. In addition, targeted polluters were mainly smaller, politically weak private enterprises, as in Zhang's piece. Therefore, it seems unlikely that prosecutors can add much permanent regulatory capacity without ongoing support from EPBs and local governments.

One implication is that the entry of new regulatory actors may not make much difference in terms of regulatory capacity, regulatory autonomy, or even environmental outcomes. Here again, an authoritarian logic is at play. More than in non-authoritarian settings, many of China's new actors, particularly citizens - and even courts and prosecutors - operate in a space defined by the party state. Citizens are unable to scale up from localized "not in my backyard" (NIMBY) protests to cross-regional or cross-national activism. Across the board, China's new environmental actors often decide that the best way to create change is by finding common ground with the state environmental authorities and helping them do their job better. EPBs also benefit from these alliances, especially when they can team up with a more powerful part of the bureaucracy, such as the judiciary, procuratorate, or police. Environmental politics are increasingly coalition politics and a winning coalition nearly always requires significant support inside the party-state. 


\section{Multipolarity and the role of the state}

The contributions in this special edition also shed light on how different actors interact in the regulatory landscape. One dominant idea is that the entry of new actors coincides with what is sometimes called a decentering of regulation. In the decentered perspective, regulation is "fragmented between social actors and between actors and the state," such that no single actor can dominate (Black 2001, p. 108). The papers discussed here illustrate another possibility: although more actors inhabit the regulatory landscape, the state retains control. We see an emergence of regulatory pluralism that is not matched by a full-fledged form of decentered regulation, marked by fragmentation of the state monopoly over regulatory power.

In all three articles, the old administrative regulators - the EPBs - as well as the local and central party-state continue to play a pivotal role in the regulatory landscape. In Zhang's study, EPBs play a central role in detecting pollution violations and setting fines, even after they come to rely on the courts for a crucial aspect of enforcement work. Along similar lines, Shi and Van Rooij's study shows that many prosecutors initiated public interest litigation at the invitation of an EPB that needed help to get the case accepted in the court. Finally, Johnson's study shows how even though strong leadership and organization help spread information, the target of mobilization remained the local government. It is clear that the administrative authorities remain at the center of the regulatory landscape, albeit with a stronger oversight from citizens and media.

In China, then, the locus of regulatory activities remains with the state, particularly the EPBs and the local government. For all that China's environmental regulatory landscape is increasingly pluralistic, few question the conventional wisdom that the state must be at the center of any serious environmental solution. Moreover, regulatory pluralism largely takes place under the aegis of a party-state willing to support new actors only insofar as their actions enhance stability and remain controllable. Inside the state, too, there has been a proliferation of agencies involved in environmental regulation. The local officials accountable for new, binding environmental targets must coordinate (or compete) with environmental court judges, prosecutors, and EPB staff. One way to view China's regulatory pluralism is as a part of a larger pluralization of Chinese politics.

\section{How entry affects the new environmental actors}

So far, little attention has been paid to the consequences of becoming involved in regulation for new actors, beyond changes to their legitimacy and accountability as regulators (Black 2008). However, entry onto the regulatory landscape can be a life-altering event for actors whose core jobs, tasks, and identities have not been regulatory, and whose new regulatory activities can sometimes undermine their other tasks. In his work on the 1964 Freedom Summer, sociologist Doug McAdam offers the observation that activism can be life-changing, a point in time that divides lives into "before" and "after" terms, an insight that we believe can be applied to actors who change their role conception and identity by entering the regulatory landscape (McAdam 1989, p. 758). This shift is particularly noticeable for actors coming from a context that is not originally regulatory or, perhaps, not even related to environmental activism.

Consider judges, for example. Judges' classic task is to act as impartial adjudicators (Shapiro 1981). Zhang's paper shows that when judges become involved in aiding EPBs in the execution of their administrative decisions, this can shift scarce resources away from the court's overall docket. In addition, becoming co-regulators with governmental agencies can undermine the court's neutrality in judging governmental decisions. 
Prosecutors are another good example of the unintended consequences of entry onto the regulatory landscape. In the Chinese system, one of prosecutors' key functions is overseeing courts through the so-called kangsheng procedure, through which parties can ask the civil law division of the procuratorate to review questionable court decisions. In criminal law cases, too, prosecutors have traditionally been seen as superior to courts and driving the criminal process. Once prosecutors become involved in regulation by initiating public interest litigation, their relationship with the court changes. Prosecutors then become a normal party in a civil procedure, subordinate to the judgment of the court and without direct rights to oversee the judiciary.

For citizens, anti-pollution activism also has wide-ranging consequences. In the broader literature on environmental activism, citizens' entry into the regulatory landscape has two effects. The first is a "learned helplessness" (cf. Lora-Wainwright et al. 2012) that activism can only lead to compensation (and not regulation), coupled with widespread pessimism (cf. Van Rooij et al. 2012). The second is the unraveling of solidarity as leaders are co-opted and only some citizens get paid. This splintering is exacerbated when activists are portrayed as opportunists and lose status in their community. Earlier studies have similarly found that the statecontrolled media and the state itself often cast environmental activists as unruly or even mentally ill (cf. Van Rooij 2010).

Clearly, reactions to a newfound regulatory role vary, and regulatory roles have occasionally brought recognition and even financial gain to some of China's leading environmental activists. Regulatory roles have brought recognition and even financial gain. In the cases presented in the papers here, the consequences of assuming a regulatory role have been more negative with rejection, conversion, and burnout all plausible possibilities. Unintended consequences can also have a significant long-term impact, such as the breakdown of social trust and the undermining of judicial oversight and neutrality. These shifts should be understood partly as the result of a situation where it is only possible for many citizens to become involved in regulation through social unrest. Inside the state, too, lack of judicial and prosecutorial independence could potentially undermine the development of rule of law if judges and prosecutors step into regulatory roles.

\section{Conclusion}

The papers in this special edition make three important contributions to the study of regulation and governance. A first implication is that regulatory pluralism can occur outside of Western liberal democracies, in places such as China, with its state-dominated economy (Huang 2008; Bremmer 2010; Halper 2010), authoritarian political system (Nathan 2003; Pei 2006; Steinfeld 2010), and tightly controlled civil society (Ashley and He 2008). The form regulatory pluralism takes in China is particular to this context. We see a form of authoritarian regulatory pluralism characterized by continued party-state dominance and a schizophrenic recognition that new actors are both necessary and, at times, threatening. As a result of concerns about social stability and regime continuity, the central and local party-state shifts between supporting and restricting the goals and activities of new regulatory actors. Under these circumstances, the worst-case scenario is that regulatory pluralism becomes a form of "regulation by escalation "(cf. Van Rooij 2012), where non-state actors can only be effective if they escalate the level of social unrest.

China's pluralizing regulatory landscape broadens our understanding of regulatory pluralism. It can no longer be seen as a phenomenon of market-based liberal democracies, and has its own logic in the authoritarian settings of China's bifurcated regulatory state. (Hsueh 2011). Under this authoritarian logic, regulatory pluralism predominantly occurs within the confines of 
a space controlled by the party-state. As such, it should be seen as part of a shift toward pluralistic, authoritarian governance (cf. Mertha 2009). Crucial here is China's turn towards a responsive form of authoritarianism (cf. Cai 2004; Weller 2008; He \& Warren 2011; Reilly 2011) that balances between giving sufficient space to new actors to prevent problems that might lead to unrest, and controlling them. (cf. Van Rooij 2012).

A second insight arises from the contrast between China and the emerging "southern" perspective on regulation. The special edition highlights some of the differences, as well as the similarities, between China and the sometimes overgeneralized conclusions of work seeking to understand the rise of regulation in the global "South." Much as the literature on the Global South suggests, China's development of regulatory pluralism occurred in a context of limited state capacity (cf. Braithwaite 2006; Chng 2012; Dubash \& Morgan 2012). Also, strikingly, the papers demonstrate the regulatory potential (and limits) of courts, similar to Thiruvengadam and Joshi's (2012) findings.

Compared to the southern regulatory literature, however, our papers on China diverge in four ways. First, there is little international influence or pressure (Braithwaite 2006; Dubash \& Morgan 2012). Second, unlike Badran's work on independent Egyptian regulators (Badran 2013), there is no sign of independent, accountable, transparent regulators emerging. Third, unlike other work documenting regulatory pluralism in places "where infrastructure services are of extremely poor quality and often non-existent" (Dubash \& Morgan 2012, p. 142) or "deliver(ing) much needed services to urban poor communities" (Chng 2012, p. 344), we see the development of regulatory pluralism despite the fact that the state has little trouble providing basic services. Finally, we see no sign of what Braithwaite hoped can happen in developing countries: the development of a regulatory society that can bypass failing state regulators (Braithwaite 2006). Rather the opposite: actors' activities are shaped directly by the party-state.

Differences between China and elsewhere in the Global South demonstrate the need for careful comparison between narrower sets of countries to better develop regulatory theory beyond the world's Western, Educated, Industrialized, Rich, and Democratic (WEIRD) countries (cf. Henrich et al. 2010; Jones 2010). To start, regime type seems like one important variable for comparison, opening up possibilities to develop and test assumptions about the relationship between the political system and the development and functioning of regulation.

The third implication is a push toward a more complicated understanding of new regulatory actors than has been present in the literature. First, actors may enter the regulatory landscape without intent to act in a regulatory manner, but still help mitigate risk as an unintended by-product of their actions (cf. Mitnick 1980, pp. 2-3). This demonstrates that common features of a state based system of regulation, such as the intent to regulate, cannot be taken for granted in a context of pluralism. This broad perspective on regulation enables us to better see the full palette of vital regulatory activities.

A second related insight is the field needs to move toward a more comprehensive definition of regulation. We cannot assume to capture regulation simply by looking for new institutions and actors that assume functions similar to state regulation (cf. Black 2001), as Hutter proposes (2006). Instead, the study of regulatory pluralism should seek a truly decentered perspective, difficult as this may be (Black 2001). Even Black, a well-known advocate of a decentered perspective, places intent at the heart of her definition (Black 2001, p. 142). In so doing, she excludes some of the key actors in China, especially citizens acting unintentionally to prevent and control pollution-related risk. A truly decentered perspective should (cf. Kottak 2009) define regulation based on what actors on the regulated landscape (including those that are regulated) see as activities that, intended or not, help prevent and control human-made risk (cf. 
Kottak 2009).${ }^{8}$ Here, the field could learn much from Tamanaha's notion of a non-essentialist approach to law, which uses a similar actor-based definition to capture what law is under legal pluralism.

A third insight is that regulatory pluralism need not coincide with the fragmentation of state control, often considered a key feature of the decentering of regulation (Black 2001). In China, the rise of new actors on the regulatory landscape occurred largely under the control and influence of the local and central party-state. As Chng (2012) puts it, new actors may operate at the "edge of the regulatory state" without state regulators losing their pivotal role. There may at least be an "anchored pluralism," to borrow Crawford's term, with the state continuing to play a central role on the regulatory landscape (Crawford 2006 following Loader \& Walker 2006).

A final insight is that entry onto the regulatory landscape does not occur in a vacuum. When citizens, civic organizations, financial institutions, or courts start to play regulatory roles, their actions are influenced by their original social and professional context. And vice versa: the entry of new actors onto the regulatory landscape may shift their position, identity, and roles in their community or profession. This has direct effects for the actors involved, possibly uprooting their lives and identities. It may also have unintended consequences for important long-term processes, such as the rule of law, social trust, and political legitimacy.

\section{Notes}

1 Our definition of regulation is both focused and broad. It is focused as it sees regulation as those activities that help prevent and control human induced risk rather than all forms of social control or influence. In other words, we focus on the restrictive function of regulation, rather than its enabling or facilitating function. At the same time the definition is broad as it does not define exactly what kind of activities regulation includes, nor do we require explicit intention to reduce risk. (Cf. Mitnick 1980: pp. 1-7; Selznick 1985; Baldwin, Scott, and Hood 1998: pp. 3-4; Baldwin and Cave 1999: pp. 1-2; Hutter 2001: pp. 8-11; Morgan and Yeung 2007: pp. 3-4)

2 We could also have called it a regulatory field or arena. We opt to call it a landscape, in part in order to highlight some of its geographical characteristics and in part for stylistic purposes.

3 One important exception is Hsueh 2011.

4 One important exception is McAllister 2005.

5 One exception is O'Rourke 2004.

6 See also Stern (2014, pp. 53-74).

7 For more on the Chinese internal evaluation system see Edin 2003; Heimer 2006; Landry 2008; Minzner 2009; Wang 2013.

8 See note 2 above for an explanation about what influenced our definition here. We opt for a more limited and broader definition of such activities than what Black proposes (2001: p. 142), which includes all forms of control, order and influence, but which requires intent and is based on the perspective of the person analysing and defining. In contrast, our definition does not require intent and uses the perspective of actors involved, yet limits it only to activities that such actors see as risk preventing and controlling.

\section{References}

Ashley JS, He P (2008) Opening One Eye and Closing the Other: The Legal and Regulatory Environment for "Grassroots" Ngos in China Today. Boston University International Law Journal 26, 29-95.

Ayres I, Braithwaite J (1992) Responsive Regulation: Transcending the Deregulation Debate. OUP, New York. 
Badran A (2013) Understanding the Egyptian Regulatory State: Independent Regulators in Theory and Practice. In Dubash NK, Morgan B (eds) The Rise of the Regulatory State of the South: Infrastructure and Development in Emerging Economies, pp. 53-74. Oxford University Press, Oxford.

Baldwin R, Cave M (1999) Understanding Regulation. Theory, Strategy and Practice. OUP, Oxford.

Baldwin R, Scott C, Hood C (1998) Introduction. In: Baldwin R, Scott C, Hood C (eds) A Reader on Regulation, pp. 1-58. OUP, Oxford.

Bartley T (2003) Certifying Forests and Factories: States, Social Movements, and the Rise of Private Regulation in the Apparel and Forest Products Fields. Politics \& Society 31, 433-464.

Bartley T (2007) Institutional Emergence in An Era of Globalization: The Rise of Transnational Private Regulation of Labor and Environmental Conditions. American Journal of Sociology 113, 297-351.

Black J (2001) Decentring Regulation: Understanding the Role of Regulation and Self-regulation in a “Post-Regulatory" World. Current Legal Problems 54, 103-146.

Black J (2008) Constructing and Contesting Legitimacy and Accountability in Polycentric Regulatory Regimes. Regulation \& Governance 2, 137-164.

Blecher MJ (2002) Hegemony and Workers' Politics in China. The China Quarterly 170, 283-303.

Braithwaite J (2006) Responsive Regulation and Developing Economies. World Development 34, 884-898.

Bremmer I (2010) The End of the Free Market: Who Wins the War between States and Corporations? Portfolio/The Penguin Group, New York.

Cai Y (2004) Managed Participation in China. Political Science Quarterly 119, 425-451.

Chng NR (2012) Regulatory Mobilization and Service Delivery at the Edge of the Regulatory State. Regulation \& Governance 6, 344-361.

Crawford A (2006) Networked Governance and the Post-regulatory State? Steering, Rowing and Anchoring the Provision of Policing and Security. Theoretical Criminology 10, 449-479.

Dubash NK, Morgan B (2012) Understanding the Rise of the Regulatory State of the South. Regulation \& Governance 6, 261-281.

Edin M (2003) State Capacity and Local Agent Control in China: CCP Cadre Management from a Township Perspective. China Quarterly 173, 35-52.

Fu H, Cullen R (2007) From Mediatory to Adjudicatory Justice, The Limits of Civil Justice Reform in China. [Last accessed 15 October 2014.] Available from URL: http://papers.ssrn.com/sol3/ papers.cfm?abstract_id=1306800.

Grabosky P (2012) Beyond Responsive Regulation: The Expanding Role of Non-state Actors in the Regulatory Process. Regulation \& Governance (forthcoming).

Gunningham N, Grabosky P, Sinclair D (1998) Smart Regulation, Designing Environmental Policy. OUP, Oxford.

Halper S (2010) The Beijing Consensus: How China's Authoritarian Model Will Dominate the Twenty-first Century. Basic Books, New York.

He B, Warren ME (2011) Authoritarian Deliberation: The Deliberative Turn in Chinese Political Development. Perspectives on Politics 9, 269-289.

Heimer M (2006) The Cadre Responsibility System and the Changing Needs of the Party. Brodsgaard and Zheng, The Chinese Communist Party in Reform: 122-138.

Henrich J, Heine SJ, Norenzayan A (2010) Most People Are Not WEIRD. Nature 466, 29.

Holzner CA (2004) The End of Clientelism? Strong and Weak Networks in a Mexican Squatter Movement. Mobilization: An International Quarterly 9, 223-240.

Hood C, Rothman H, Baldwin R (2001) The Government of Risk: Understanding Risk Regulation Regimes. OUP, Oxford.

Hsueh R (2011) China's Regulatory State: A New Strategy for Globalization. Cornell University Press, Ithaca, NY.

Huang Y (2008) Capitalism with Chinese Characteristics: Entrepreneurship and the State. CUP, New York. Hutter BM (2001) Regulation and Risk: Occupational Health and Safety on the Railways. OUP, Oxford. 
Hutter BM (2006) The Role of Non-state Actors in Regulation. London School of Economics and Political Science, Discussion Paper No 37. Centre for Analysis of Risk and Regulation, London.

Jones D (2010) A WEIRD View of Human Nature Skews Psychologists' Studies. Science(Washington) 328(5986), 1627-1627.

Kottak CP (2009) Mirror for Humanity: A Concise Introduction to Cultural Anthropology, 7th Edition, McGraw-Hill, New York. 7. McGraw-Hill, New York.

Landry PF (2008) Decentralized Authoritarianism in China: The Communist Party's Control of Local Elites in the Post-Mao Era. Cambridge University Press, New York.

Liebman B (2011) A Populist Threat to China's Courts? In Gallagher M, Woo M (eds) Chinese Justice: Civil Dispute Resolution in Post-Reform China, pp. 269-314. CUP, New York.

Lo CWH, Tang SY (2006) Institutional Reform, Economic Changes and Local Environmental Management in China. Environmental Politics 15, 190-210.

Loader I, Walker N (2006) Necessary Virtues: The Legitimate Place of the State in the Production of Security. In: Wood J, Dupont B (eds) Democracy, Society and the Governance of Security, pp. 165-195. Cambridge University Press, Cambridge.

Lora-Wainwright A (2012) Regulatory Repertoires and the Limited Potential of Rural Environmental Activism in China. Paper presented at the Symposium on China's New Environmental Regulators, 24 August 2012, Beijing.

Lora-Wainwright A, Zhang A, Wu Y, Van Rooij B (2012) Learning to Live with Pollution: How Environmental Protesters Redefine Their Interests in a Chinese Village. The China Journal 68, 106-124.

Lorentzen PL (2013) Regularizing Rioting: Permitting Public Protest in an Authoritarian Regime. International Quarterly Journal of Political Science 8(2), 127-158.

Ma X, Ortolano L (2000) Environmental Regulation in China, Institutions, Enforcement, and Compliance. Rownman \& Littlefield Publishers, Lanham.

McAdam D (1989) The Biographical Consequences of Activism. American Sociological Review 54, 744-760.

McAllister LK (2005) Public Prosecutors and Environmental Protection in Brazil. In: Romero A, West SE (eds) Environmental Issues in Latin America and the Caribbean, pp. 207-231. Springer, Dordrecht.

Mertha A (2009) “Fragmented Authoritarianism 2.0:” Political Pluralization in the Chinese Policy Process. China Quarterly 200, 995-1012.

Michelson E (2007) Climbing the Dispute Pagoda: Grievances and Appeals to the Official Justice System Rural China. American Sociological Review 72, 459-485.

Minzner CF (2006) Xinfang: An Alternative to Formal Chinese Legal Institutions. Stanford Journal of International Law 42, 103-179.

Minzner CF (2009) Riots and Cover-Ups: Counterproductive Control of Local Agents in China. University of Pennsylvania. Journal of International Law 31, 53-123.

Minzner CF (2011) China’s Turn Against Law. American Journal of Comparative Law 4, 935-984.

Mitnick B (1980) The Political Economy of Regulation: Creating, Designing, and Removing Regulatory Forms. Columbia University Press, New York.

Mol APJ (2009) Urban Environmental Governance Innovations in China. Current Opinion in Environmental Sustainability 1(1), 96-100.

Morgan B, Yeung K (2007) An Introduction to Law and Regulation: Texts and Materials. CUP, Cambridge, UK.

Nathan AJ (2003) Authoritarian Resilience. Journal of Democracy 14(1), 6-17.

OECD (Organisation for Economic Co-operation \& Development) (2007) OECD Environmental Performance Reviews: China. OECD Publishing, Paris.

O'Rourke D (2004) Community-Driven Regulation, Balancing Development and the Environment in Vietnam. MIT Press, Cambridge, MA.

Pei M (2006) China's Trapped Transition: The Limits of Developmental Autocracy. Harvard University Press, Cambridge, MA. 
Peters A, Koechlin L, Förster T, Zinkernagel GF (2009) Non-state Actors as Standard Setters. CUP, Cambridge, UK.

Reilly J (2011) Strong Society, Smart State: The Rise of Public Opinion in China's Japan Policy. Columbia University Press, New York.

Van Rooij B, McAllister LK (2014) Environmental Challenges in Middle-Income Countries: A Comparison of Enforcement in Brazil, China, Indonesia and Mexico. In: Ginsburg T, Peerenboom RP (eds) Law and Development of Middle Income Countres, pp. 288-306. Cambridge University Press, Cambridge.

Sabel CF, Zeitlin J (2008) Learning from Difference: The New Architecture of Experimentalist Governance in the EU. European Law Journal 14, 271-327.

Selznick P (1985) Focusing Organisational Research on Regulation. In: Noll RG (ed) Regulatory Policy and the Social Sciences, pp. 363-386. University of California Press, Berkeley.

Shapiro M (1981) Courts, A Comparative and Political Analysis. The University of Chicago Press, Chigaco. Snow DA, Cress DM, Downey L, Jones AW (1998) Disrupting the "Quotidian:" Reconceptualizing the Relationship between Breakdown and the Emergence of Collective Action. Mobilization: An International Quarterly 3, 1-22.

Steinfeld ES (2010) Playing Our Game, Why China's Rise Doesn't Threaten the West. OUP, New York.

Stern RE (2013) Environmental Litigation in China: A Study in Political Ambivalence. CUP, New York.

Stern RE (2014) The Political Logic of China's New Environmental Courts. The China Journal (July), 53-74.

Stockmann D (2012) Media Commercialization and Authoritarian Rule in China. CUP, Cambridge, UK.

Su Y, He X (2010) Street As Courtroom: State Accommodation of Labor Protests in South China. Law \& Society Review 44, 157-184.

Tamanaha BZ (2000) A Non-Essentialist Version of Legal Pluralism. Journal of Law and Society 27, $296-321$.

Thiruvengadam AK, Joshi P (2012) Judiciaries as Crucial Actors in Southern Regulatory Systems: A Case Study of Indian Telecom Regulation. Regulation \& Governance 6, 327-343.

Tilt B (2007) The Political Ecology of Pollution Enforcement in China: A Case of Sichuan's Rural Industrial Sector. China Quarterly 192, 915-933.

Van Rooij B (2010) The People Vs. Pollution: Understanding Citizen Action against Pollution in China. The Journal of Contemporary China 19(63), 55-79.

Van Rooij B (2012) The People's Regulation: Citizens and Implementation of Law in China. Columbia Journal of Asian Law 25(2), 116-180.

Van Rooij B, Lo CHW (2010) Fragile Convergence, Understanding Variation in the Enforcement of China's Industrial Pollution Law. Law \& Policy 32, 14-37.

Van Rooij B, Lora-Wainwright A, Wu Y, Zhang Y (2012) The Compensation Trap: The Limits of Community-based Pollution Regulation in China. Pace Environmental Law Review 29, 701-745.

Wang A (2013) The Search for Sustainable Legitimacy: Environmental Law and Bureaucracy in China. Harvard Environmental Law Review 37(2), 367-440.

Weller R (2012) Responsive Authoritarianism and Blind-Eye Governance in China. In: Bandelj N, Solinger DJ (eds) Socialism Vanquished, Socialism Challenged: Eastern Europe and China, 1989-2009, pp. 83-102. Oxford University Press, Oxford.

Weller RP (2008) Regime Responses. Responsive Authoritarianism. In: Gilley B, Diamond L (eds) Political Change in China: Comparisons with Taiwan, pp. 117-138. Lynne Rienner Publishers, Boulder.

World Bank/SEPA (State Environmental Protection Administration) (2007) Costs of Pollution in China: Economic Estimates of Physical Damages (Conference Edition). World Bank, Washington, DC. 